\title{
Pengembangan perangkat pembelajaran matematika dengan pendekatan scientific pada pokok bahasan aritmetika sosial untuk SMP kelas VIII
}

\author{
Vuvut Selviana, Rini Nurhakiki* \\ Universitas Negeri Malang, Jl. Semarang No. 5 Malang, Jawa Timur, Indonesia \\ *Penulis korespondensi, Surel: rini.nurhakiki.fmipa@um.ac.id
}

Paper received: 01-12-2021; revised: 15-12-2021; accepted: 31-12-2021

\begin{abstract}
Abstrak
Penyelenggaraan pembelajaran matematika yang berkualitas tidak lepas dari peran guru dalam mengembangkan perangkat pembelajaran yang berkualitas. Tujuan dari penelitian ini adalah untuk menghasilkan perangkat pembelajaran berupa RPP dan LKS materi barisan aritmatika dan barisan geometri untuk siswa SMP kelas IX yang valid, praktis, dan efektif. Pengembangan perangkat pembelajaran ini memodifikasi model pengembangan Plomp yang terdiri atas: (1) tahap investigasi awal, (2) tahap desain, (3) tahap realisasi, dan (4) tahap tes, evaluasi, dan revisi. Berdasarkan analisis pengembangan diperoleh hasil bahwa perangkat pembelajaran yang dikembangkan dinyatakan valid, praktis, dan efektif.
\end{abstract}

Kata kunci: perangkat pembelajaran; pendekatan scientific; aritmetika sosial

\section{Pendahuluan}

Pembelajaran matematika salah satunya bertujuan agar siswa memahami konsep matematika, menjelaskan keterkaitan antarkonsep dan mengaplikasikan konsep atau algoritma secara luwes, akurat, efisien, dan tepat dalam pemecahan masalah (Depdiknas dalam Nizarwati, 2009). Tujuan pembelajaran ini menunjukkan bahwa siswa tidak hanya dituntut untuk memahami konsep matematika saja, melainkan juga dapat menerapkannya dalam berbagai situasi kehidupan sehari-hari yang relevan. Oleh karena itu, pembelajaran matematika seharusnya menyediakan pengalaman-pengalaman belajar yang dapat mempersiapkan siswa untuk mengaplikasikan pengetahuan yang dimiliki dalam menyelesaikan masalah kehidupan sehari-hari.

Usaha pencapaian tujuan pembelajaran ini tentu tidak lepas dari metode pembelajaran yang digunakan. Saat ini, masih banyak kegiatan pembelajaran yang menggunakan metode ceramah dalam membelajarkan suatu materi sehinga daya serap materi oleh siswa minim. Hal ini seperti yang diungkapkan oleh Ariani dan Harianto (2010), "Sekitar 80\% siswa mengomentari bahwa metode ceramah yang cenderung "top down" dan sentralistik dari para guru di kelas cenderung sangat membosankan sekalipun sudah bertendensi student oriented atau student center, terkesan formal, dan sangat minim persentase daya serap materi dan atensi peserta didik."

Selain itu, berdasarkan pengamatan yang dilakukan oleh penulis selama menjadi tentor privat matematika siswa SMP, masih sering ditemukan siswa yang tidak dapat menyelesaikan masalah aritmetika sosial. Siswa tidak dapat mengaplikasikan pengetahuan mereka mengenai konsep aritmetika sosial untuk menyelesaikan soal-soal aplikasi aritmetika sosial. Pengamatan tersebut diperkuat penulis dengan memberikan satu soal aplikasi dengan materi aritmetika sosial dan satu pertanyaan terkait proses pembelajaran yang digunakan dalam pembelajaran. Hasil menunjukkan bahwa 70\% atau 7 dari 10 siswa yang mengerjakan soal 
tidak dapat menyelesaikan soal yang diberikan dengan benar dan kesepuluh siswa menyatakan bahwa pembelajaran yang dilakukan di kelas adalah dengan metode ceramah yang mereka anggap membosankan.

Masalah terkait ketidakmampuan siswa dalam mengaplikasikan konsep yang mereka dapatkan untuk menyelesaikan soal aplikasi aritmetika sosial ini memerlukan pendekatan pembelajaran yang dapat meningkatkan ketrampilan siswa dalam menyelesaikan masalah aplikasi konsep. Salah satu pendekatan yang bisa dijadikan solusi dari masalah tersebut adalah pendekatan scientific (ilmiah), karena pendekatan scientific merupakan suatu cara atau mekanisme pembelajaran untuk memfasilitasi siswa agar mendapatkan pengetahuan dan ketrampilan dengan prosedur yang didasarkan pada metode ilmiah (Kemdikbud, 2013).

Menurut Peraturan Menteri Pendidikan dan Kebudayaan Republik Indonesia Nomor 81A tahun 2013, pendekatan scientific terdiri dari 5 pengalaman belajar pokok, yaitu : (1) mengamati, siswa melakukan kegiatan membaca, mendengar, menyimak, melihat (tanpa atau dengan alat); (2) menanya, siswa mengajukan pertanyaan tentang informasi yang dipahami atau informi tambahan tentang apa yang diamati; (3) mengumpulkan informasi; (4) mengolah informasi, siswa mengasosiasikan hasil pengamatan dan informasi yang terkumpul menjadi kesimpulan; dan (5) mengomunikasikan, siswa menyampaikan hasil pengamatan, kesimpulan berdasarkan hasil analisis secara lisan, tertulis, atau media lainnya

Namun, untuk menyelesaikan masalah di atas tidak hanya dengan mengubah pendekatan pembelajaran yang digunakan. Guru hendaknya menyusun suatu perangkat pembelajaran sebelum kegiatan pembelajaran dilakukan. Menurut Trianto (2007:68), perangkat pembelajaran merupakan segala sesuatu yang digunakan oleh guru dalam mengelola kegiatan pembelajaran dan terdiri atas silabus, Rencana Pelaksanaan Pembelajaran (RPP), Lembar Kegiatan Siswa (LKS), buku siswa, instrumen evaluasi, dan media pembelajaran. Perangkat pembelajaran yang baik tentu membantu guru untuk dapat menyelenggarakan pembelajaran yang berkualitas bagi siswa.

Berdasarkan uraian di atas, akan dikembangkan perangkat pembelajaran matematika berupa RPP dan LKS dengan pendekatan scientific pada pokok bahasan aritmetika sosial. RPP adalah bentuk perencanaan yang menggambarkan kegiatan-kegiatan yang akan dalam suatu kegiatan pembelajaran untuk mengarahkan siswa mencapai Kompetensi Dasar (KD). Sedangkan LKS merupakan bahan ajar berisi tugas yang harus diselesaikan oleh siswa dengan mengikuti langkah-langkah atau petunjuk yang ada agar siswa dapat belajar secara terarah untuk mencapai KD. Dengan demikian, perangkat pembelajaran dengan pendekatan scientific adalah RPP dan LKS dimana aktivitas pembelajarannya terdiri dari 5 langkah pokok sesuai pendekatan scientific yaitu mengamati, menanya, mengumpulkan informasi, mengolah informasi dan mengomunikasikan. Sehingga perangkat pembelajaran yang akan dikembangkan dapat membantu siswa dalam menyelesaikan masalah pada pokok bahasan aritmetika sosial.

\section{Metode}

Penelitian ini merupakan penelitian pengembangan, yaitu pengembangan perangkat pembelajaran dengan pendekatan scientific pada pokok bahasan aritmetika sosial yang mengacu pada model yang dikemukakan oleh Plomp (Hobri, 2010). Model pengembangan yang dikemukakan oleh Plomp terdiri atas 5 tahap, yaitu 1) tahap investigasi awal, 2) tahap desain, 3) tahap realisasi, 4) tahap evaluasi, tes, dan revisi, dan 5) tahap implementasi. 
Namun, penelitian ini hanya dilakukan sampai pada tahap tes, evaluasi, dan revisi dikarenakan ketersediaan biaya dan waktu pelaksanaan.

Pada penelitian ini, dilakukan 3 uji untuk mengetahui kualitas produk yang dikembangkan, yaitu uji kevalidan, uji kepraktisan, dan uji keefektifan. Namun untuk uji keefektifan terbatas untuk mengukur keefektifan pada aspek ketrampilan. Uji kevalidan dilakukan untuk melihat apakah produk yang telah dikembangkan peneliti telah sesuai dengan teori pengembangan perangkat pembelajaran dan lima tahapan pokok pada pendekatan scientific. Uji kepraktisan dilakukan untuk mengetahui keterterapan perangkat pembelajaran yang dihasilkan dalam proses pembelajaran, apakah mudah dan menyenangkan untuk digunakan atau tidak. Sedangkan uji keefektifan dilakukan untuk mengetahui sejauh mana produk yang dihasilkan dapat membantu siswa mempelajari materi yang diajarkan.

Uji kevalidan menggunakan angket validasi RPP dan LKS yang diisi oleh 1 orang dosen matematika dan 1 orang guru matematika SMP yang telah berpengalaman di bidangnya. Uji kepraktisan dilakukan menggunakan angket uji kepraktisan RPP yang diisi oleh 1 orang guru dan 2 orang observer, serta angket respon siswa yang diisi oleh 16 orang siswa kelas VII sebagai subjek uji coba. Uji keefektifan dilakukan dengan melihat nilai hasil pengerjaan kuis 1 pada pertemuan 1, PR pada pertemuan 2 dan kuis 2 pada pertemuan 3.

Teknik analisis data hasil uji kevalidan dan kepraktisan yang dilakukan sesuai teknik analisis dalam Hobri (2010), yaitu: 1) melakukan rekapitulasi data penilaian produk ke dalam tabel yang meliputi aspek, indikator, dan nilai untuk masing-masing validator, 2) menentukan rata-rata nilai hasil penilaian dari semua validator untuk setiap indikator, 3) menentukan rerata nilai untuk setiap aspek, dan 4) menentukan persentase kevalidan atau persentase kepraktisan, yaitu nilai rerata total dari rerata nilai untuk semua aspek. Selanjutnya, hasil yang diperoleh akan dibandingkan dengan kriteria kevalidan atau kepraktisan perangkat pembelajaran seperti pada Tabel 1 .

Tabel 1. Kriteria Kevalidan atau Kepraktisan Perangkat Pembelajaran

\begin{tabular}{cll}
\hline Persentase & Kategori & Keterangan \\
\hline $85 \leq P<100$ & Sangat valid/sangat praktis & Tidak perlu revisi \\
$70 \leq P<85$ & Valid/praktis & Tidak perlu revisi \\
$55 \leq P<70$ & Cukup valid/cukup praktis & Revisi sebagian \\
$40 \leq P<55$ & Kurang valid/kurang & Revisi sebagian \\
& praktis & \\
$0 \leq P<40$ & Tidak valid/tidak praktis & Revisi total \\
\hline
\end{tabular}

Sedangkan, teknik analisis data hasil uji keefektifan dilakukan dengan menganalisis hasil belajar pada setiap pertemuan. Apabila berdasarkan hasil penilaian kuis dan PR yang dilakukan diperoleh hasil bahwa $80 \%$ siswa mendapatkan nilai di atas 78, maka perangkat pembelajaran dikatakan efektif. Namun, apabila persentase siswa yang mendapat nilai di atas 78 kurang dari 80\%, maka perangkat pembelajaran belum dikatakan efektif.

\section{Hasil dan Pembahasan}

Hasil dari pengembangan perangkat pembelajaran ini adalah berupa RPP dan LKS dengan pendekatan scientific pada pokok bahasan aritmetika sosial. RPP dikembangkan 
untuk tiga pertemuan, masing-masing $2 \times 40$ menit, sedangkan LKS yang dihasilkan terdiri dari LKS 1 tentang nilai keseluruhan barang, LKS 2A tentang untung, LKS 2B tentang rugi, dan LKS 3 tentang bruto, netto dan tara. LKS yang dikembangkan terdiri atas : (1) halaman sampul yang memuat judul LKS, identitas kelompok, kompetensi dasar, indikator pencapaian kompetensi, dan petunjuk belajar; (2) halaman lembar kerja dengan pendekatan scientific yang terdiri dari lima kegiatan pokok yaitu mengamati, menanya, mengumpulkan informasi, mengolah informasi, dan mengomunikasikan; dan (3) halaman latihan soal.

Data yang diperoleh dari uji kevalidan terdiri dari data hasil uji kevalidan RPP dan hasil uji kevalidan LKS. Analisis data hasil uji kevalidan RPP oleh validator disajikan pada Tabel 2 sebagai berikut.

Tabel 2 Analisis Data Hasil Uji Kevalidan RPP oleh Validator

\begin{tabular}{lllll}
\hline No. & Aspek yang Dinilai & $\begin{array}{l}\text { Persentase } \\
\text { Kevalidan }\end{array}$ & $\begin{array}{l}\text { Kriteria } \\
\text { Kevalidan }\end{array}$ & Keterangan \\
\hline 1. & Kelayakan Isi & $95 \%$ & Sangat Valid & Tidak Revisi \\
2. & $\begin{array}{l}\text { Kesesuaian dengan pendekatan } \\
\text { scientific }\end{array}$ & $89 \%$ & Sangat Valid & Tidak Revisi \\
3. & Kebahasaan dan Kegrafisan & $91 \%$ & Sangat Valid & Tidak Revisi \\
\hline
\end{tabular}

Secara keseluruhan aspek terhadap RPP yang telah dikembangkan, diperoleh peresentase kevalidan sebesar $92 \%$ dan berada pada kriteria kevalidan sangat valid. Dengan demikian, dapat disimpulkan bahwa RPP yang dikembangkan valid dan tidak perlu revisi. Namun, peneliti tetap melakukan revisi berdasarkan saran dan masukan dari validator untuk menyempurnakan RPP yang dikembangkan.

Tabel 3 Analisis Data Hasil Uji Kevalidan LKS oleh Validator

\begin{tabular}{cllll}
\hline No. & Aspek yang Dinilai & $\begin{array}{l}\text { Persentase } \\
\text { Kevalidan }\end{array}$ & $\begin{array}{l}\text { Kriteria } \\
\text { Kevalidan }\end{array}$ & Keterangan \\
\hline 1. & Kelayakan Isi & $94 \%$ & Sangat Valid & Tidak Revisi \\
2. & Kebahasaan & $88 \%$ & Sangat Valid & Tidak Revisi \\
3. & Tampilan & $94 \%$ & Sangat Valid & Tidak Revisi \\
4. & $\begin{array}{l}\text { Kesesuaian dengan pendekatan } \\
\text { scientific }\end{array}$ & $88 \%$ & Sangat Valid & Tidak Revisi \\
\hline
\end{tabular}

Pada Tabel 3 disajikan hasil analisis data dari uji kevalidan LKS yang dikembangkan. Secara keseluruhan, LKS yang telah dikembangkan memperoleh persentase kevalidan 91\% yang berada pada kriteria kevalidan sangat valid. Berdasarkan hasil tersebut dapat disimpulkan bahwa LKS yang telah dikembangkan valid dan tidak perlu dilakukan revisi. Namun, peneliti tetap melakukan revisi berdasarkan saran dan masukan validator untuk menyempurnakan LKS yang dikembangkan.

Selain uji kevalidan, produk yang dikembangkan berupa RPP dan LKS diuji kepraktisannya. Analisis data hasil uji kepraktisan RPP disajikan pada Tabel 4 sebagai berikut. 
Tabel 4 Analisis Data Hasil Uji Kepraktisan RPP oleh Praktisi dan Observer

\begin{tabular}{|c|c|c|c|c|}
\hline No. & Aspek yang Dinilai & $\begin{array}{l}\text { Persentase } \\
\text { Kepraktisan }\end{array}$ & $\begin{array}{l}\text { Kriteria } \\
\text { Kepraktisan }\end{array}$ & Keterangan \\
\hline 1. & $\begin{array}{l}\text { Kesesuaian waktu yang disediakan } \\
\text { dengan proses pembelajaran secara } \\
\text { keseluruhan. }\end{array}$ & $75 \%$ & Praktis & $\begin{array}{l}\text { Revisi } \\
\text { sebagian }\end{array}$ \\
\hline 2. & $\begin{array}{l}\text { Tingkat ketercapaian tujuan } \\
\text { pembelajaran setelah proses } \\
\text { pembelajaran selesai. }\end{array}$ & $75 \%$ & Praktis & $\begin{array}{l}\text { Tidak perlu } \\
\text { revisi }\end{array}$ \\
\hline 3. & $\begin{array}{l}\text { Keefektifan pemanfaatan sumber } \\
\text { belajar dan media yang tercantum } \\
\text { dalam RPP oleh siswa dalam proses } \\
\text { pembelajaran. }\end{array}$ & $92 \%$ & $\begin{array}{l}\text { Sangat } \\
\text { Praktis }\end{array}$ & $\begin{array}{l}\text { Tidak perlu } \\
\text { revisi }\end{array}$ \\
\hline 4. & $\begin{array}{l}\text { Kesesuaian langkah pembelajaran } \\
\text { yang dicantumkan pada RPP dan } \\
\text { implementasinya dalam kelas. }\end{array}$ & $83 \%$ & Praktis & $\begin{array}{l}\text { Tidak perlu } \\
\text { revisi }\end{array}$ \\
\hline 5. & $\begin{array}{l}\text { Kemampuan RPP menjadikansiswa } \\
\text { aktif dan kreatif dalam proses } \\
\text { pembelajaran. }\end{array}$ & $92 \%$ & $\begin{array}{l}\text { Sangat } \\
\text { Praktis }\end{array}$ & $\begin{array}{l}\text { Tidak perlu } \\
\text { revisi }\end{array}$ \\
\hline 6. & $\begin{array}{l}\text { Kemampuan RPP mendorong siswa } \\
\text { mencari tahu dari berbagai sumber } \\
\text { belajar, dengan melakukan } \\
\text { observasi, bukan diberi tahu } \\
\text { (kegiatan mengamati). }\end{array}$ & $100 \%$ & $\begin{array}{l}\text { Sangat } \\
\text { Praktis }\end{array}$ & $\begin{array}{l}\text { Tidak perlu } \\
\text { revisi }\end{array}$ \\
\hline 7. & $\begin{array}{l}\text { Kemampuan RPP mendorong siswa } \\
\text { merumuskan masalah dan bukan } \\
\text { hanya menyelesaikan masalah } \\
\text { (kegiatan menanya). }\end{array}$ & $75 \%$ & Praktis & $\begin{array}{l}\text { Tidak perlu } \\
\text { revisi }\end{array}$ \\
\hline 8. & $\begin{array}{l}\text { Kemampuan RPP mengarahkan } \\
\text { siswa untuk mengolah informasi dari } \\
\text { hasil pengamatan maupun } \\
\text { mengumpulkan informasi (kegiatan } \\
\text { mengumpulkan dan mengolah } \\
\text { informasi) }\end{array}$ & $75 \%$ & Praktis & $\begin{array}{l}\text { Tidak perlu } \\
\text { revisi }\end{array}$ \\
\hline 9. & $\begin{array}{l}\text { Kemampuan RPP untuk mendorong } \\
\text { siswa menyampaikan hasil } \\
\text { pengamatan dan kesimpulan yang } \\
\text { telah dibuat. }\end{array}$ & $75 \%$ & Praktis & $\begin{array}{l}\text { Tidak perlu } \\
\text { revisi }\end{array}$ \\
\hline 10. & $\begin{array}{l}\text { Instrumen penilaian mudah } \\
\text { digunakan dalam proses } \\
\text { pembelajaran. }\end{array}$ & $92 \%$ & $\begin{array}{l}\text { Sangat } \\
\text { Praktis }\end{array}$ & $\begin{array}{l}\text { Tidak perlu } \\
\text { revisi }\end{array}$ \\
\hline 11. & $\begin{array}{l}\text { Kemampuan RPP menciptakan rasa } \\
\text { senang peserta didik dalam proses } \\
\text { pembelajaran }\end{array}$ & $100 \%$ & $\begin{array}{l}\text { Sangat } \\
\text { Praktis }\end{array}$ & $\begin{array}{l}\text { Tidak perlu } \\
\text { revisi }\end{array}$ \\
\hline
\end{tabular}

Secara keseluruhan, diperoleh persentase kepraktisan RPP yang dikembangkan adalah 85\%. Skor ini menunjukkan bahwa RPP yang dikembangkan berada dalam kriteria kepraktisan sangat praktis. Dengan demikian, revisi terhadap RPP yang dikembangkan tidak perlu dilakukan. Namun untuk kesempurnaan RPP yang dihasilkan, dilakukan revisi berdasarkan saran dan masukan dari praktisi dan observer yaitu menyesuaikan alokasi waktu pada RPP dengan waktu yang dibutuhkan pada saat uji coba RPP. 
Tabel 5 Analisis Data Hasil Uji Kepraktisan LKS oleh Siswa Subjek Uji Coba

\begin{tabular}{|c|c|c|c|c|}
\hline No. & Aspek yang Dinilai & $\begin{array}{l}\text { Persentase } \\
\text { Kepraktisan }\end{array}$ & $\begin{array}{l}\text { Kriteria } \\
\text { Kepraktisan }\end{array}$ & Keterangan \\
\hline 1. & $\begin{array}{l}\text { Kemudahan informasi, } \\
\text { petunjuk, dan pertanyaan } \\
\text { untuk dipahami }\end{array}$ & $84 \%$ & Praktis & Tidak Perlu Revisi \\
\hline 2. & $\begin{array}{l}\text { Kedekatan masalah yang } \\
\text { diambil dengan lingkungan } \\
\text { siswa }\end{array}$ & $80 \%$ & Praktis & Tidak Perlu Revisi \\
\hline 3. & $\begin{array}{l}\text { Ketersediaan kesempatan } \\
\text { bagi siswa dalam } \\
\text { mengungkapkan bahasa } \\
\text { sendiri }\end{array}$ & $83 \%$ & Praktis & Tidak Perlu Revisi \\
\hline 4. & $\begin{array}{l}\text { Susunan aktivitas dalam LKS } \\
\text { membimbing siswa-siswa } \\
\text { menemukan sendiri konsep } \\
\text { aritmetika sosial }\end{array}$ & $77 \%$ & Praktis & Tidak Perlu Revisi \\
\hline 5. & $\begin{array}{l}\text { Ketersediaan kesempatan } \\
\text { bagi siswa untuk terlibat aktif } \\
\text { menemukan konsep }\end{array}$ & $77 \%$ & Praktis & Tidak Perlu Revisi \\
\hline 6. & $\begin{array}{l}\text { LKS dapat digunakan sebagai } \\
\text { bahan ajar mandiri }\end{array}$ & $84 \%$ & Praktis & Tidak Perlu Revisi \\
\hline 7. & $\begin{array}{l}\text { Respon positif dari siswa } \\
\text { meliputi rasa senang, } \\
\text { semangat, mendorong } \\
\text { kreativitas dan imajinasi }\end{array}$ & $89 \%$ & Sangat Praktis & Tidak Perlu Revisi \\
\hline 8. & $\begin{array}{l}\text { Penggunaan bahasa yang baik } \\
\text { dan mudah dipahami }\end{array}$ & $91 \%$ & Sangat Praktis & Tidak Perlu Revisi \\
\hline 9. & $\begin{array}{l}\text { Jenis dan ukuran huruf } \\
\text { mudah dibaca }\end{array}$ & $89 \%$ & Sangat Praktis & Tidak Perlu Revisi \\
\hline 10. & Tampilan LKS menarik & $81 \%$ & Praktis & Tidak Perlu Revisi \\
\hline
\end{tabular}

Secara keseluruhan, persentase kepraktisan LKS yang dikembangkan adalah 83\%. Hal ini menunjukkan bahwa LKS yang dikembangkan berada dalam kriteria kepraktisan praktis sehingga tidak perlu direvisi. Namun demikian, peneliti tetap melakukan revisi terhadap bagian-bagian yang memiliki kekurangan berdasarkan saran dari subjek uji coba, khususnya pada bagian menanya LKS .

Uji keefektifan perangkat pembelajaran dilihat dari hasil analisis nilai hasil belajar pada setiap pertemuan. Pada Tabel 6 disajikan data hasil perolehan nilai siswa subjek uji coba. 
Tabel 6 Data Perolehan Nilai Siswa Subjek Uji Coba

\begin{tabular}{rllll}
\hline No & Nama & Kuis I & PR & Kuis II \\
\hline 1 & FKA & 93 & 90 & 83 \\
2 & FNY & 93 & 85 & 74 \\
3 & MRD & 73 & 79 & 77 \\
4 & NACK & 83 & 79 & 88 \\
5 & MAF & 93 & 80 & 82 \\
6 & MMM & 75 & 80 & 83 \\
7 & NAS & 77 & 75 & 79 \\
8 & RPA & 81 & 90 & 81 \\
9 & MRHA & 83 & 85 & 81 \\
10 & HFN & 82 & 83 & 78 \\
11 & DKF & 90 & 85 & 83 \\
12 & DAA & 90 & 90 & 85 \\
13 & BAB & 95 & 100 & 100 \\
14 & APDC & 81 & 85 & 82 \\
15 & ARA & 92 & 83 & 80 \\
16 & ADA & 100 & 100 & 90 \\
\hline
\end{tabular}

Hasil pengerjaan kuis 1 pada pertemuan 1 menunjukkan bahwa persentase siswa yang mendapat nilai lebih dari atau sama dengan 78 adalah $81,25 \%$. Hasil pengerjaan PR pada pertemuan 2 menunjukkan bahwa persentase siswa yang mendapat nilai lebih dari atau sama dengan 78 adalah 93,75\%. Hasil pengerjaan kuis 2 pada pertemuan 3 menunjukkan bahwa persentase siswa yang mendapat nilai lebih dari atau sama dengan 78 adalah 87,5\%. Berdasarkan hasil di atas, dapat dikatakan bahwa perangkat pembelajaran yang dikembangkan sudah efektif karena hasil belajar pada setiap pertemuan telah memenuhi criteria keefektifan.

\section{Simpulan}

Kelebihan dari perangkat pembelajaran berupa RPP dan LKS yang dikembangkan adalah (1) melalui lima kegiatan mengamati, menanya, mengumpulkan informasi, mengasosiasi, dan mengomunikasikan siswa dapat mengembangkan kreativitas, mengembangkan kemampuan merumuskan pertanyaan untuk berfikir kritis, mengembangkan sikap teliti dan jujur, meningkatkan kemampuan berkomunikasi dan menghargai pendapat orang lain; (2) perangkat pembelajaran dapat meningkatkan keaktifan belajar siswa dalam proses pembelajaran; 3) LKS yang dikembangkan bersifat kontekstual; (4) LKS yang dikembangkan memiliki tampilan yang menarik; dan (5) perangkat pembelajaran dapat menimbulkan rasa senang siswa. Sedangkan kekurangan perangkat pembelajaran yang dikembangkan adalah penilaian sikap secara individu yang membutuhkan bantuan observer sebagai bahan pertimbangan guru model untuk menilainya memungkinkan perangkat pembelajaran yang dikembangkan tidak dapat diterapkan dalam kelas dengan jumlah siswa lebih dari 16 dan alokasi waktu yang dibutuhkan untuk LKS cenderung lebih dari waktu yang direncanakan.

Berdasarkan hasil penelitian yang telah dilakukan peneliti, maka saran yang direkomendasi, yaitu : (1) hasil pengembangan berupa perangkat pembelajaran dengan pendekatan scientific ini diharapkan dapat digunakan sebagai alternatif dalam pembelajaran pokok bahasan aritmetika sosial untuk siswa SMP kelas VII; (2) uji coba perangkat pembelajaran yang dikembangkan terbatas pada kelompok kecil dengan enam belas siswa 
sebagai subjeknya, sehingga diharapkan bagi penulis yang lain untuk melakukan uji coba perangkat pembelajaran pada kelompok besar untuk mendapatkan hasil yang lebih meyakinkan; (3) pokok bahasan perangkat pembelajaran yang dikembangkan terbatas pada aritmetika sosial sehingga diharapkan penulis lain dapat mengembangkan perangkat pembelajaran dengan pendekatan scientific pada pokok bahasan yang lain; dan (4) bagi penulis lain disarankan agar mengembangkan perangkat pembelajaran dengan pendekaran scientific pada pokok bahasan aritmetika sosial yang mengukur keefektifan dari semua aspek penilaian yaitu sikap, pengetahuan, dan ketrampilan.

\section{Daftar Rujukan}

Ariani, N., \& Haryanto, D. (2010). Pembelajaran multimedia di sekolah. Jakarta: Prestasi Pustaka.

Hobri, H. (2010). Metodologi penelitian pengembangan (aplikasi pada penelitian pendidikan matematika). Jember: Pena Salsabila.

Pendidikan, P. M., \& Nomor, K. R. I. (2013). 81A tahun 2013 tentang Implementasi Kurikulum Pedoman Umum Pembelajaran. Jakarta: Kementrian Pendidikan dan Kebudayaan RI.

Nizarwati, N., Hartono, Y., \& Aisyah, N. (2009). Pengembangan perangkat pembelajaran berorientasi konstruktivisme untuk mengajarkan konsep perbandingan trigonometri siswa kelas X SMA. Jurnal Pendidikan Matematika, 3(2), 57-72.

Trianto, S. P., \& Pd, M. (2007). Model pembelajaran terpadu dalam teori dan praktek. Jakarta: Prestasi Pustaka. 